\title{
Memaknai Strategic Communication
}

Helpris Estaswara ${ }^{1}$, Umar Halim $^{2}$, Ahmad
Badari Burhan

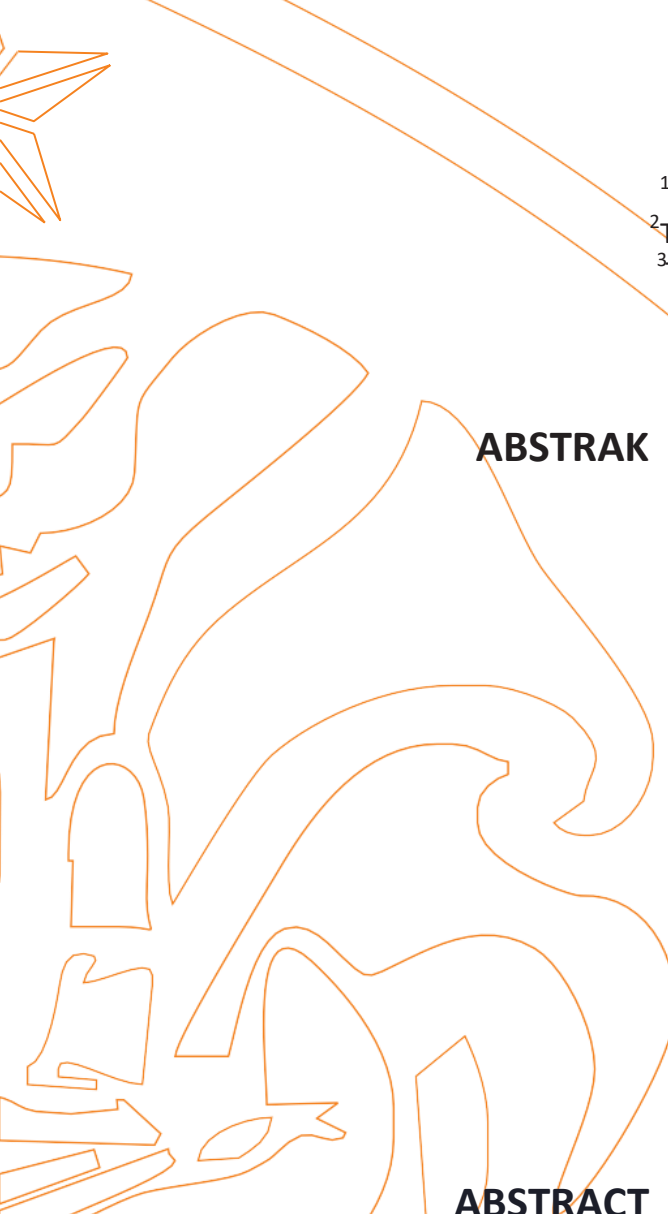

Fakultas Ilmu Komunikasi, Universitas Pancasila

Jl. Srengseng Sawah, Jagakarsa, Jakarta Selatan 12640

${ }^{1}$ Telp: 081310488088, E-mail: helpris.estaswara@univpancasila.ac.id

2Telp: 08161688916, E-mail: umarhalim@univpancasila.ac.id

3Telp: 087877493178, E-mail: ahmadbadariburhan@univpancasila.ac.id

ABSTRACT

Strategic communication is a relatively new concept in communication studies.

Formerly, the concept of strategic communication was widely used in military and governance studies related to international relations. As a new concept, it is not surprising that there are many different perspectives on the meaning of strategic communication, related to the position of communication studies, similarity with public relations and corporate communication, and paradigm used. This article has explored various meanings of strategic communication with the aim of interpreting communication-based strategic communication by rejecting taken-for-granted attitudes as part of management strategy. Based on above explanations and by using the literature review method, strategic communication is interpreted as a process of communication between actors in the organization that is manifested in the form of interactions that mutually understanding and work together to achieve organizational goals based on the postmodernism paradigm.

CoverAge:

Keywords: strategic communication, postmodernism, communication actors

Journal of Strategic

Communication

Vol. 11, No. 1, Hal. 1-11.

September 2020

Fakultas Ilmu Komunikasi,

Universitas Pancasila 


\section{PENDAHULUAN}

\section{PENDAHULUAN}

Konsep strategic communication-atau sering diterjemahkan sebagai komunikasi strategis-merupakan bidang kajian yang relatif baru dalam disiplin komunikasi (Thomas \& Stephens 2015, Werder et al 2018, Nothhaft et al 2018). Awalnya, konsep strategic communication banyak digunakan dalam kajian militer dan ilmu pemerintahan terkait dengan hubungan internasional (Farwell, 2012). Baru sekitar satu dekade ini, strategic communication mulai banyak diteliti dan ditulis oleh akademisiakademisi komunikasi (Holtzhausen \& Zerfass 2014). Di Indonesia, kajian tentang strategic comunication belum banyak dibahas secara akademis, khususnya dalam disiplin ilmu komunikasi. Tidak mengherankan jika penelitian dan publikasi ilmiah di bidang ini pun jarang ditemukan di jurnal-jurnal nasional.

Sebagai sebuah konsep, strategic communication memiliki pemahaman (arti) yang lebih luas dari advertising, marketing communication, public relations, organizational communication maupun corporate communications (Falkheimer \& Heide 2014), atau bahkan dengan IMC (Integrated Marketing Communications) sekali pun (Hallahan et al 2007). Gagasan atas strategic communication sendiri banyak diartikan sebagai penggabungan antara corporate communications, public relations, organizational communication, dan marketing communication yang berbasis pendekatan management strategy (Falkheimer \& Heide 2014).

Cara berpikir seperti ini terkesan memermudah realitas komunikasi dan bahkan berpotensi menghambat perkembangan disiplin komunikasi itu sendiri (Hallahan et al 2007). Pertama, cara berpikir seperti ini akan selalu menempatkan teori-teori komunikasi tradisional (linear/one-way) dengan perspektif fungsional sebagai fokus kajian strategic communication di era interaktif. Jelaslah bahwa gagasan ini memiliki kontradiksi pemahaman antara teori dengan realitas yang ada. Kedua, cara berpikir seperti ini juga cenderung tidak menempatkan teori-teori komunikasi sebagai fokus kajian, namun selalu meletakkan disiplin ilmu lain, khususnya management strategy (Falkheimer \& Heide 2014), sebagai penggerak utama (main driver)-di mana komunikasi diposisikan sebagai fungsi manajemen (management fashion) (van Ruler 2018).
Memang, secara akademis, strategic communication sebagai kajian baru menyisakan banyak perdebatan di satu sisi, namun juga memberikan ruang bagi pertumbuhan di sisi lainnya. Hal seperti ini tidaklah mengherankan. Konsep baru bagaimana pun juga akan selalu menciptakan pro dan kontra sampai ide tersebut menjadi kuat secara teoretis dan diakui oleh para akademisi (Estaswara 2015, 2016). Faktanya, kajian strategic communication dalam disiplin ilmu komunikasi baru lahir tahun 2007 sejak dikenalkannya untuk pertama kali pada edisi awal International Journal of Strategic Communication (van Ruler 2018). Kemudian, teorisasinya diperkuat dengan diterbitkan Handbook of Strategic Communication tahun 2014. Selanjutnya, guna memeringati 10 tahun strategic communication, dalam konferensi International Communication Association (ICA) di San Diego, AS, tahun 2017, dibuatlah sebuah "konferensi terbatas" (pre-conference) dengan tema "Future Directions in Strategic Communication: Towards Second Decade of an Emerging Field" (Nothhaft et al 2018). Paper-paper yang dipresentasikan dalam "konferensi terbatas" tersebut, kemudian diterbitkan dalam edisi khusus International Journal of Strategic Communication tahun 2018.

Walaupun sudah banyak dibahas, strategic communication masih belum terbangun menjadi sebuah teori yang solid, karena cenderung tidak menempatkan disiplin komunikasi sebagai inti dari kajian ini, alih-alih mendukung penuh dan bahkan taken-for-granted atau menerima begitu saja posisi komunikasi dalam kajian management strategy-yang dipandang hanya sebagai fungsi manajemen (management fashion). Pemikiran seperti ini jelas-jelas menempatkan disiplin komunikasi sekedar "pendukung" atau "instrumen" bagi manajemen (Holtzhausen \& Zerfass 2014, Shandu 2009). Tidak hanya itu, dalam satu dekade terakhir, mengutip van Ruler (2018) dan Nothhaft et al (2018), berbagai publikasi ilmiah tentang strategic communication yang telah diterbitkan di International Journal of Strategic Communication masih banyak yang belum menempatkan teori-teori komunikasi sebagai fokus utama dalam kajiannya.

Memang, sejak tulisan Hallahan et al (2007) dengan judul "Redefining Strategic Communication" dipublikasikan di International Journal of Strategic Communication-di mana artikelnya tersebut dibangun dalam kerangka disiplin ilmu komunikasi-strategic communication mulai menjadi pusat perhatian. Sejak saat itu, kajian ini banyak diteliti, ditulis, 
diperdebatkan, dan dikembangkan oleh akademisi bidang komunikasi (Holtzhausen \& Zerfass 2014). Meski demikian, sejauh ini bisa dikatakan bahwa sejarah penelitian strategic communication masih relatif baru dan belum berkembang, terutama dalam disiplin ilmu komunikasi.

Berangkat dari penjaraban di atas, maka tujuan artikel ini adalah untuk memaknai strategic communication secara komprehensif guna mendapatkan suatu gambaran yang holistik sehingga dapat memberikan landasan konseptual bagi pengembangan peneorisasian strategic communication sebagai bagian dari ilmu komunikasi-dengan menolak sikap takenfor-granted posisi komunikasi sebagai management fashion dalam pengelolaan oraganisasi (perusahaan).

\section{TINJAUAN PUSTAKA}

Tahap pertama dalam memahami strategic communication dilakukan dengan mengeksplorasi atas maknanya. Eksplorasi makna strategic communication, diawali dengan melakukan analisis atas definisi. Hal ini mengingat bahwa definisi pada dasarnya memberikan penjelasan tentang makna atau batasan dan ciri-ciri dari strategic communication. Sejauh ini, beberapa scholar telah mendefinisikan strategic communication dengan cara berbeda-beda dan menurut pemahamannya masing-masing (Thomas \& Stephens 2015). Seperti definisi yang dikenalkan oleh Argenti, Howell, \& Beck (2005, h. 83) yang menyatakan "strategic communication is aligned with the company's overall strategy, to enhance its strategic positioning." Dalam kesempatan yang lain, Argenti (2017) mengatakan bahwa definisi tersebut memiliki makna yang sama dengan definisi yang pernah diungkapkan Styne (2003, h. 177), yang menyatakan bahwa strategic communication adalah "deliberate design of a communication strategy to interpret an organization's vision, values, goals and intentions to its audiences."

Dengan memahami definisi di atas, sekilas terkesan sulit dibedakan dengan pemahaman tentang public relations. Grunig mengatakan bahwa public relations merupakan "bridging activity" antar organisasi yang harus dilembagakan (Grunig 2006) sebagai fungsi dari strategic management (Grunig 2011). Kata "aligned" dalam definisi Argenti, Howell, \& Beck (2005) pada dasarnya selaras dengan konsep "bridging activity" yang digagas Grunig. Berbasis hasil penelitian dengan mewawancarai lebih dari 50 orang CEO, CFO, heads of corporate communication and investor relations di berbagai industri, Argenti,

Howell, \& Beck $(2005,88)$ kemudian menyimpulkan strategic communication adalah tentang "how communication can add to the process of translating broadroom strategy to front-line execution, as well as the ability communications to support strategy development." Penjelasan ini tidak lebih dari "bridging activity" untuk tidak mengatakan bahwa komunikasi hanyalah sekedar "interpreter", "translator" dan "supporter" saja (Holtzhausen \& Zerfass 2014).

Terkait dengan penjelasan tersebut, Argenti (2017) mengakui bahwa konstruksi pemikirannya tentang "aligned" dalam strategic communication berbasiskan pada perspektif management strategy. Di artikel yang sama, sebenarnya Argenti (2017) juga mengatakan bahwa jika strategic communication ditinjau dari perspektif ilmu komunikasi, merupakan alternatif sudut pandang yang sangat membantu dalam upaya pengembangan teori strategic communication. Tapi, penggunaan perspektif komunikasi dalam strategic communication bukanlah fokus pemikirannya-tanpa harus mengritisi lebih lanjut ataupun menolak (Argenti 2017). Perbedaan cara pandang ini sebenarnya tidak mengherankan, mengingat strategic communication adalah persinggungan antara management strategy dengan communication (Thomas \& Stephens 2015).

Gagasan tentang "aligment" (aligned)terjemahannya adalah "penyelarasan"-dalam peneorisasian strategic communication faktanya telah banyak diungkapkan di berbagai publikasi ilmiah. Namun, ide ini dianggap hanya sebatas konsepsional (Volk \& Zerfass 2018). Banyak pemikir umumnya tidak menjelaskan secara lebih mendalam (rinci) tentang bagaimana "aligment" dalam strategic communication harus dilakukan. Di sisi lain, mereka juga menyatakan bahwa kajian strategic communication sampai saat ini merupakan objek dari "aligment". Seharusnya, strategic communication tidak hanya menjadi objek, namun juga subjek dalam konteks "aligment" (Volk \& Zerfass 2018). Berdasarkan gagasan ini dan memahami adanya kekosongan pemahaman tentang makna "aligment", Volk dan Zerfass (2018) kemudian mengartikan aligment dalam strategic communication, sebagai berikut (h. 443):

"Alignment of strategic communication can be understood as the varying degree of linkage between the communication strategy and the overall organizational strategy (primary alignment) and of the coherence between communication activities, including brands, images, symbols, messages, or topics, and between them and communication strategy (secondary alignment) for the purpose of achieving organizational goals. This is 
the outcome of an ongoing alignment process,

which can be managed more or less intensively."

Konsepsi tentang aligment di atas bagaimana pun juga lebih maju dari ide-ide yang diungkapkan Argenti, Howell, \& Beck (2005) maupun Argenti (2017). Dengan pemikirannya itu, Volk \& Zerfass (2018) berusaha melepaskan strategic communication dari dominasi perspektif management strategy dan memosisikan ilmu komunikasi sebagai fokus utama. Khusus untuk primary aligment-di mana tataran inilah yang menjadi persoalan penting-telah didudukkan sejajar dengan management strategy. Berdasarkan penjelasan aligment di atas, dapat dikatakan bahwa communication strategy selaras dengan management strategy melalui suatu proses penyelarasan yang berlangsung terus-menerus (ongoing aligment process) untuk mencapai tujuan perusahaan.

Meski demikian, kembali merujuk Argenti, Howell, \& Beck (2005), Argenti (2017), serta Grunig (2006), pemikiran Volk \& Zerfass (2018) tersebut masih bersifat konseptual dan perlu diuji kebenarannya di lapangan. Hal ini mengingat bahwa penelitian Argenti, Howell, \& Beck (2005) dan Argenti (2017) terhadap C-suite executives (CEO, CFO, CMO dan bahkan CCO), serta penjelasan Grunig (2006) tentang implementasi komunikasi pada tataran corporate dalam konteks strategic public relations (temuan dari excellent study-nya), mengungkapkan hasil di mana C-suite executives menganggap bahwa komunikasi harus "mendukung"-dalam semua artian yang positif, meski hanya sebagai management fashionpengelolaan perusahaan dalam mencapai tujuannya.

Lebih lanjut, definisi lainnya yang lebih populer dan banyak dikutip para akademisi di seluruh dunia, diungkapkan oleh Hallahan et al (2007, h. 3), yang mendefinisikan strategic communication sebagai berikut:

"The purposeful use of communication by an organization (all kind) to fulfill its mission [...]. It further implies that people will be engaged in deliberate communication practice on behalf of organizations, causes, and social movements."

Definisi Hallahan et al, di atas dapat diartikan bahwa komunikasi bertujuan untuk membantu perusahaan dalam mencapai misinya dengan melibatkan orang-orang dalam praktek komunikasinya. Fokus pemikiran Hallahan et al, hanya pada tujuan komunikasi. Gagasan seperti ini akan membatasi pemahaman strategic communication dan tidak memberikan perhatian terhadap "kualitas komunikasi" yang membuat komunikasi menjadi strategis (van Ruler 2018).

Bahkan, pada tataran tertentu, pemahamannya memiliki kemiripan dengan definisi yang pernah diungkapkan Styne (2003) (Argenti 2017).

Menyelesaikan berbagai perbedaan konseptual atas strategic communication yang diterjemahkan sebagai "aligment" (aligned) di mana pengertiannya memiliki kesamaan dengan "bridging activity" dalam public relations, atau pun perdebatan atas komunikasi yang bertujuan (purposeful use of communication atau deliberate design of a communication), pada faktanya telah dibawa ke ranah paradigma. Public relations dan corporate communications merupakan kajian yang berbasis pendekatan management strategy dengan menggunakan paradigma modernisme, di mana teori-teori besar, kategorisasi universal, dan standar-standar umum harus diberlakukan dalam organisasi guna mencapai tujuan (Argenti 2017, Grunig 2006) yang selalu bersifat fungsionalis, instrumental, dan sistemik (Shandu 2009). Jika strategic communication benar-benar ingin keluar dari dominasi paradigma modernisme, dan memberikan perhatian terhadap "kualitas komunikasi" (van Ruler 2018), maka kajian ini harus dianggap sebagai sebuah pendekatan (approach) dalam konteks komunikasi intra dan inter-organisasi yang berbasis paradigma postmodernisme (Klerk \& Verwey 2013).

Paradigma postmodernisme pada dasarnya mengabaikan universalitas dan keseragaman serta standar-standar yang bersifat umum. Postmodernisme juga menolak teori-teori besar (grand narratives), di mana kesemuanya itu digantikan dengan kesadaran dan toleransi sosial atas perbedaan, ambiguitas, dan konflik (Lyotard 1992, Klerk \& Verwey 2013). Dengan berbasis pada paradigma ini, makna strategic communication akan mampu melampaui disiplin "sejenis" yang sudah lama mapan, seperti disiplin public relations atau corporate communications, dan bahkan organizational communication serta marketing communication (Klerk \& Verwey 2013, van Ruler 2018, Falkheimer \& Heide 2014).

\section{METODE}

Memaknai strategic communication dalam artikel ini dapat dilakukan dengan menggunakan literatur review. Literature review merupakan suatu tinjuan yang komprehensif atas berbagai penelitian (publikasi ilmiah) yang telah diterbitkan sebelumnya terkait dengan topik yang diteliti-strategic communication-dengan cara mengungkapkan apa yang sudah diketahui dan apa yang belum diketahui tentang strategic communication, di mana dalam artikel ini, bertujuan untuk melakukan penyelidikan 
baru terkait dengan pengembangan teori (Denney \& Tewksbury 2012) dengan mengeksplorasi makna dan memaknai strategic communication. Di samping itu, literature review juga dapat digunakan untuk mengekstrasi dan membangun ide-ide baru dari karya ilmiah (scientific journal) para akademisi dan teorisasinya tentang strategic communication yang kemudian disintesiskan dengan sumber-sumber lain yang relevan (Bolderston 2008).

Karya ilmiah tentang strategic communication dari para akademisi yang digunakan sebagai sumber utama dalam artikel ini bisa ditelusuri dari edisi khusus International Journal of Strategic Communication yang diterbitkan tahun 2007 dan 2018, serta beberapa artikel yang relevan dengan masalah pembangunan teori stratergic communication dalam Handbook of Strategic Communication yang diterbitkan pada tahun 2014. Di samping itu, beberapa tulisan di jurnal ilmiah yang relevan dengan topik penelitian juga digunakan untuk diperbandingkan dan disintesiskan, seperti public relations, corporate communication dan management. Dengan demikian, artikel ini menggunakan literatur yang berjenis jurnal ilmiah dan buku.

Berdasarkan langkah-langkah dalam literature review yang diungkapkan oleh Bolderston (2008, 87-90), dua tahapan penting yang harus dilakukan untuk menjaga kualitas literatur review, yaitu searching the literatur dan appraising the literature sudah dipenuhi dalam artikel ini. Pertama, terkait dengan searching the literatur, peneliti harus memiliki kemampuan mencari literatur tentang strategic communication yang relevan. Dengan mengakses semua artikel di International Journal of Strategic Communication-sebuah jurnal yang didedikasikan untuk pengembangan teorisasi strategic communication-bisa dikatakan bahwa literatur yang dianalisis dalam tulisan ini merupakan primary source yang trustable terkait dengan topik penelitian.

Kedua, tentang appraising the literature di mana peneliti diharuskan pula "hanya" menggunakan literatur primer, juga telah dilakukan dalam penelitian ini. Beberapa artikel penting terkait pembangunan teori strategic communication yang ditulis oleh para pemikir utama dalam studi ini, seperti Ansgar Zerfass (University of Leipzig, Germany), Betteke van Ruler (University of Amsterdam), Derina R. Holtzhausen (Lamar University), Kirk Hallahan (Colorado State University), Dejan Verčič (University of Ljubljana), maupun Paul A. Argenti (Tuck School of Business at
Dartmouth) dan James E. Grunig (University of Maryland)-di mana dua nama terakhir adalah tokoh berpengaruh di bidang corporate communication dan public relations-telah dianalisis dalam artikel ini sebagai primary source. Hal ini mengingat juga bahwa tulisan para tokoh intelektual tersebut bisa dianggap sebagai manifestasi atas perkembangan teorisasi strategic communication.

Berdasarkan penjabaran di atas, literature review dalam tulisan ini dapat dikatakan sebagai sebuah proses yang secara berurutan dan berulangulang dalam melakukan tinjauan atas publikasipublikasi ilmiah yang ditulis oleh tokoh-tokoh utama dalam pembangunan teori strategic communication serta dibandingkan dan disintesiskan yang kemudian dikaitkan dengan topik-topik yang bersinggungan berdasarkan artikel yang ditulis oleh para akademisi di bidang public relations, corporate communication, maupun management dengan tujuan untuk memaknai strategic communication guna memberikan kontribusi pemikiran bagi keseluruhan bangunan pengetahuan tentang strategic communication (Levy \& Ellis 2006).

\section{HASIL DAN PEMBAHASAN}

\section{Mendefinisikan Strategic Communication}

Berangkat dari hasil literature review tentang perdebatan pemikiran dan keterbatasan definisi atau pemaknaan atas strategic communication, kami menganggap perlu untuk merumuskan definisi baru. Sebuah definisi yang diharapkan mampu keluar dari jeratan modernisme dengan basis paradigma postmodernisme dan menempatkan disiplin ilmu komunikasi sebagai penggerak utama (main driver) dalam strategic communication. Dengan demikian strategic communication dapat didefinisikan sebagai:

"Proses komunikasi yang berlangsung secara terus-menerus yang dilakukan oleh aktor-aktor komunikasi (individu, kelompok dan organisasi), internal maupun eksternal, dalam rangka saling memahami untuk bekerjasama mencapai tujuan organisasi."

Definisi di atas harus diakui banyak dipengaruhi oleh berbagai gagasan dari Volk \& Zerfass (2018) tentang aligment dalam strategic communication, maupun Hallahan et al (2007), Argenti, Howell \& Beck (2005), serta Styne (2003). Tapi, untuk mampu keluar dari kungkungan modernisme, fokus utama dalam definisi ini telah diarahkan kepada "aktor komunikasi" - di mana aktor yang dimaksud dalam pemaknaan ini tidak terbatas hanya pada organisasi (perusahaan). Dengan menitikberatkan pada aktor 
komunikasi, maka strategic communication sudah memberikan perhatian kepada semua actor dengan semua keunikan dan kekhasan perilakunya yang terlibat dalam pengelolaan organisasi dalam mencapai tujuannya. Dengan cara seperti ini, fokus kajian bukan lagi pada strategi dan program komunikasi serta efektivitasnya (tujuan komunikasi) yang mana fokus kajian seperti ini memandang disiplin ilmu komunikasi hanya sebagai "instrumen" saja.

Definisi kami tersebut pada dasarnya juga dibangun dengan mengasumsikan bahwa organisasi (perusahaan) merupakan perilaku komunikasi (organization as communication) (Schoeneborn \& Vàsques, 2017). Artinya, kegiatan komunikasi dari semua aktor yang terlibat dan kualitas komunikasi yang terbentuk menjadi aktivitas yang paling menentukan bagi organisasi dalam mencapai tujuannya. Ide tersebut tak lepas dari pemahaman bahwa inti dari organisasi adalah orang-orang yang mengelolanya. Ide ini selaras dengan berbagai definisi management di mana orang-orang menjadi pusat kajian. Merujuk Kaehler dan Grundei (2019, h. 9-10), beberapa definisi management yang berfokus pada people adalah sebagai berikut:

1. "Management is working with and through other people to accomplish the objectives of both the organization and its members" (Montana \& Charnov 2008, h. 2).

2. "Management means getting things done through other people - whether that be on the people plane (leading and linking) or on the information plane (controlling and communicating)" (Mintzberg 2009, h. 168).

3. "Management is the activity of getting things done with the aid of people and other resources" (Boddy 2017, h. 11).

4. "Management: The act of working with and through a group of people to accomplish a desired goal or objective in an efficient and effective manner" (Gulati, Mayo, \& Nohrian 2017, h. 8).

5. "Management is getting work done through others" (Williams 2018, h. 3).

Kelima definisi di atas, sudah menyatakan secara jelas bahwa pengelolaan organisasi dan efektivitasnya sangat ditentukan oleh orang-orang (people) yang ada di dalamnya. Maka, Jika disimpulkan secara umum, manajemen yang berbasis people adalah pengelolaan organisasi (perusahaan) yang dilakukan oleh orang-orang dalam rangka mencapai tujuan. Dengan demikian, dapat dikatakan bahwa semua orang yang ada di dalam organisasi dan terlibat dalam pengelolaannya-baik langsung maupun tidak-

adalah aktor terpenting yang menentukan keberhasilan perusahaan untuk mencapai tujuannya.

Dalam mengelola dan mencapai tujuan organisasi, orang-orang harus saling memahami dan bekerjasama melalui proses komunikasi yang berlangsung secara terus-menerus, baik bersifat one-way, two-way, ataupun multi-way communication (van Ruler 2018), baik komunikasi yang berada pada tataran intrapersonal, interpersonal, intragroup, intergroup, intraorganisasi, dan interorganisasi (Madalina 2016, Holmström et al 2010), atau gejala komunikasi pada tataran makro (struktur sosial-budaya), meso (organisasi), dan mikro (individu dan kelompok) (Shandu 2009, McPhee \& Zaug 2000).

Dengan berbasis pada penjelasan tersebut dan kembali mencermati definisi strategic communication yang kami ajukan, terdapat empat ide dasar yang perlu untuk diperhatikan, yaitu: (1) aktor-aktor komunikasi; (2) saling memahami; (3) bekerjasama, dan; (4) proses komunikasi yang berlangsung secara terus-menerus, dalam konteks pencapaian tujuan organisasi.

\section{Aktor-Aktor Komunikasi}

Pemahaman tentang aktor-aktor dalam strategic communication harus mewakili semua aktor yang ada. Tak hanya organisasi saja atau perusahaan, tapi melingkupi semua aktor yang memiliki kepentingan dengan organisasi, seperti individu dan kelompok, baik internal atau eksternal-selain organisasi itu sendiri yang diwakili oleh pihak manajemen. Dalam public relations, advertising, corporate communications, organizational communication, dan marketing communication, organisasi selalu menjadi satusatunya aktor komunikasi. Sedang sisanya (public atau stakeholder) sekedar objek komunikasi. Jika strategic communication hanya dibangun sebagai "kepanjangan" dari disiplin-disiplin tersebut, maka peran individu dan kelompok menjadi terabaikan (Falkheimer \& Heide 2014).

Dalam ilmu public relations sendiri mengenal berbagai aktor yang disebut dengan public atau stakeholder. Demikian juga strategic communication, aktor-aktor komunikasi dalam kajian ini juga bisa dikatakan sebagai stakeholderyang sering didefinisikan sebagai any group or individual who can affect or is affected by the achievement of the firm's objectives (Freeman 1984, h. 25). Dalam definisi ini, manajemen (pengelola perusahaan yang sah secara hukum) tidak pernah dianggap sebagai stakeholder atau public. Merekalah yang mendefinisikan dan menentukan siapa stakeholder atau public bagi 
perusahaan. Memang, kajian seperti ini selalu berbasis pada paradigma modernitas, di mana pihak manajemen merupakan aktor utama-yang menentukan semua kebijakan komunikasi guna memengaruhi stakeholder atau public. Jika peneorian strategic communication dibangun untuk bisa keluar dari dominasi paradigma modernitas, maka semua pihak-mulai dari manajemen itu sendiri, pemegang saham, karyawan, serikat pekerja (profesional), wartawan, regulator, masyarakat, kelompok sosial-politik lainnnya, konsumen, kompetitor sampai financial institution, baik individu, kelompok atau organisasi, merupakan aktor-aktor komunikasi yang menjadi fokus kajian. Pemikiran seperti inilah yang membuat komunikasi menjadi strategic.

Pemahaman di atas sangat berbeda dengan penjelasan Hallahan et al (2008), Argenti, Howell \& Beck (2005), dan Styne (2003) yang mengatakan bahwa strategic communication merupakan komunikasi yang disengaja dari organisasi (sebagai aktor utama) dan karena itu secara teoritis membutuhkan aktor yang bertujuan (manajemen), pengambilan keputusan yang rasional dan disengaja, serta implementasi dan evaluasi program komunikasi strategis. Pemikiran ini masih menempatkan organisasi atau perusahaan sebagai aktor utama dan satu-satunya, di mana aktor-aktor lain hanya sebagai objek komunikasi (Torp 2014). Di sisi lain, kajian seperti ini tentu saja menggunakan paradigma modernis di mana tujuan komunikasi yang direalisasikan melalui strategi, program kerja, sampai evaluasi selalu menjadi fokus kajian (Hallahan et al 2008, Argenti, Howell \& Beck 2005, Styne 2003, Argenti 2017, Grunig 2006)

Faktanya, organisasi merupakan kumpulan individu dan pada satu titik bisa dikatakan juga kumpulan individu yang berkelompok dan memiliki tujuan yang sama (Kaehler \& Grundei 2019). Di banyak kasus, disiplin ilmu yang berbasis komunikasi tradisional dan mencari kebenaran ilmiah atas dasar standar-standar umum, cenderung gagal dalam memahami realitas aktoraktor komunikasi ketika menjelaskan kompleksitas permasalahan organisasi dalam mencapai tujuannya di era teknologi informasi hari ini. Dengan membuka ruang bagi kehadiran aktoraktor komunikasi tersebut (adanya kesetaraan kedudukan), maka kami percaya akan memberikan sudut pandang yang berbeda dalam pengembangan kajian strategic communication.

Dengan cara berpikir seperti ini, strategic communication diharapkan bisa melepaskan diri dari kekangan aliran modernitas yang lebih mengagung-agungkan model komunikasi satu arah (one-way), paling tidak two-way asimetris, menuju ke postmodernitas (Klerk \& Verwey 2013, Holtzhausen 2000). Pemikiran kami ini memberikan ruang bagi praktik komunikasi yang bersifat dua arah simetris, bahkan komunikasi banyak arah (many-way) (van Ruler 2018). Demikian juga, kajian strategic communication bisa memberikan ruang bagi praktik komunikasi pada tataran mikro, di mana kualitas komunikasi pada tingkatan ini-yang merupakan hasil konstruksi makna dari tataran makro-sangat memengaruhi komunikasi yang berlangsung pada tataran meso (organisasi) (Shandu 2009).

\section{Interaksi: Saling Memahami}

Saling memahami dapat diciptakan melalui interaksi. Interaksi sendiri merupakan kondisi yang harus ada (necessary condition) bagi eksistensi perusahaan (Cooren, 2006, Marchiori \& Bulgacov 2012). Bagaimana pun juga, pada kenyataannya, organisasi selalu dibangun melalui interaksi dan hubungan antar manusia (aktor) yang ada di dalamnya (Cheney et al 2011). Bahkan, komunikasi sehari-hari yang dilakukan oleh orang-orang ketika berinteraksi (daily conversation) merupakan persoalan penting dalam organisasi (Mumby 2011). Maka, dengan melibatkan banyak aktor komunikasi dalam organisasi, pemikiran strategic communication bisa dikembangkan ke arah logika "interaksi" alih-alih hanya sebagai "aksi" yang bersifat satu arah (van Ruler 2018, Shandu 2009).

Dengan memahami komunikasi sebagai interaksi akan memberikan ruang bagi terciptanya kesetaraan kedudukan dari para aktor komunikasi yang ada dalam organisasi. Dengan memegang prinsip seperti ini, pesan komunikasi bukan lagi dominasi satu pihak (manajemen) saja, di mana aktor-aktor komunikasi lainnya (stakeholders) diasumsikan "mati" atau keberadaannya diposisikan hanya sebagai penerima pesan an sich tanpa memiliki kuasa atas pesan-atau minimal hanya memiliki hak menginterpretasikan pesan secara bebas, itu pun dalam konteks conditioning. Pemahaman ini dapat dikatakan lebih maju dari gagasan-gagasan sebelumnya karena aktor-aktor komunikasi (semuanya) tidak lagi dijadikan sebagai objek, namun sudah menjadi subjek dalam strategic communication, di mana interaksi merupakan bentuk konstruksi atas realitas dan co-creating meaning antar aktor (Marchiori \& Bulgacov 2012). Dengan demikian, interaksi antar aktor di dalam organisasi, di semua bentuk dan tingkatan komunikasi, merupakan kajian utama dalam strategic communication (van Ruler 2018).

Faktanya, pemikiran yang berbasis pendekatan management strategy, hanya memahami 
komunikasi sebagai tindakan atau aksi yang bertujuan menimbulkan effect (pengaruh) kepada stakeholder dalam upaya manajemen mencapai tujuan organisasi (Klerk \& Verwey 2013). Kungkungan logika ini harus dibongkar dan diperluas dengan memandang komunikasi sebagai interaksi. Dengan interaksi yang simetris, komunikasi dapat dikatakan sebagai pertukaran makna (simbol) yang terjadi dalam konteks intrapersonal, interpersonal, dengan berbagai posisi, interpersonal dan intergroup dalam kelompok, formal dan non-formal, maupun internal dan eksternal, intraorganisasi, interorganisasi, organisasi dengan individu dan kelompok. Dengan cara berpikir seperti ini, strategic communication akan mampu menjelaskan berbagai realitas konflik, konsensus, sampai budaya (share meaning) yang terjadi dalam organisasi melalui interaksi dinamis aktor-aktor komunikasi (multi-actors), yang bersifat multidirection, serta khas (unik) (van Ruler 2018).

Berdasarkan pemikiran tersebut, strategic communication dapat dikatakan juga sebagai proses komunikasi dalam rangka membangun hubungan yang setara dan saling memahami antar aktor komunikasi. Hubungan setara dalam interaksi mengasumsikan bahwa semua aktor adalah peserta aktif (active participant), dan bukan lagi sebagai active receivers atau hanya active observer saja (McAuley at al 2007). Jika demikian, maka potensi terjadi konflik bisa dibendung, konflik dapat diselesaikan, konsensus dapat dicapai, dan budaya organisasi (share meaning) dapat tercipta melalui terbangunnya suatu interaksi yang saling memahami. Saling memahami dalam sistem budaya organisasi atau sistem kerja dalam konteks profesionalisme (Shandu 2009), bagaimana pun juga merupakan syarat mutlak dalam membangun kerjasama. Pemikiran ini akhirnya akan membentuk learning organization di mana interaksi yang terjadi secara terus-menerus (proses) dan saling memahami antar aktor komunikasi pada tingkatan individu, kelompok, dan organisasi, bisa dikatakan sebagai sebuah proses belajar dalam rangka beradaptasi dengan lingkungan bisnis yang cepat berubah di era informasi (Baratianu 2015). Berbasiskan pada pemikiran ini, tujuan perusahaan dalam learning organization, dan juga strategic communication, bukan pada penciptaan profit (keuntungan) semata, namun kemampuan adaptasi sebuah organisasi (Davis \& Daley 2008).

\section{Bekerjasama}

Kerjasama merupakan suatu aktivitas yang dilakukan oleh dua orang atau lebih, kelompok kecil, maupun kumpulan orang-orang. Kerjasama tidak bisa dilakukan oleh pihak-pihak yang berkonflik. Memang benar, mengharapkan bahwa dalam suatu organisasi tidak ada konflik adalah persoalan yang mustahil. Konflik tidak bisa dihindari dalam organisasi (Turkalj et al 2008). Konflik sendiri memiliki bermacam bentuk, mulai dari friksi (gesekan) sosial, ketidaksetujuan, perselisihan yang timbul antara individu atau kelompok ketika kepercayaan atau tindakan dari satu atau lebih anggota tidak bisa diterima oleh individu atau kelompok. Konflik juga memiliki tingkatan, dari intrapersonal, interpersonal, intragroup, intergroup, intraorganisasi sampai interorganisasi (Madalina 2016). Terjadinya konflik dalam semua bentuk dan tingkatan tersebut dapat diantisipasi melalui komunikasi yang reflektif dan sensitif (Holmström et al 2010).

Kerjasama yang efektif dapat terjalin jika terjadi komunikasi yang saling memahami dengan memegang teguh prinsip reflektif dan sensitif guna mereduksi konflik. Pemikiran ini selaras dengan ide van Ruler (2018) tentang kualitas komunikasi yang tidak terakomodasi dalam definisi strategic communication yang digagas oleh Hallahan et al (2007), Argenti, Howell \& Beck (2005), atau Styne (2003). Berdasarkan keseluruhan uraian di atas, maka strategic communication bisa dikatakan sebagai proses yang berlangsung secara terusmenerus (continue) melalui interaksi untuk menciptakan situasi yang saling memahami antar aktor-aktor komunikasi guna meningkatkan kualitas kerjasama (efisiensi) dan akhirnya berujung pada tercapainya tujuan organisasi (efektivitas).

Tujuan organisasi atau perusahaan dalam strategic communication dengan paradigma postmodernisme bukanlah profit (keuntungan finansial saja). Sehingga, tujuan organisasi harus dipahami sebagai susunan dari berbagai interaksiyang merupakan bentuk manifestasi atas praktik komunikasi-yang saling memahami antar aktor, di mana interkasi tersebut harus bisa memfasilitasi pembangunan pengetahuan bersama (sharing knowledge) sebagai dasar kerjasama dalam rangka menciptakan keunggulan kompetitif (Davis \& Daley 2008). Dengan demikian, aktivitas kerjasama dalam kajian strategic communication dapat pula disebut sebagai praktik komunikasi antar aktor yang bertujuan membangun organisasi yang unggul.

\section{Proses Komunikasi}

Dalam menciptakan situasi saling memahami dan bekerjasama untuk mencapai tujuan organisasi di mana aktor-aktor komunikasi menjadi fokus utama tidak ada rumusan atau standar umum yang bisa ditetapkan layaknya cara pandang dalam paradigma modernitas (Klerk \& Verwey 2013). Dalam pandangan postmodernis, realitas dilihat 
sebagai suatu hubungan yang kompleks dan interaksi yang tidak terkendali di era informasi, sehingga penting untuk memahami proses komunikasi yang terkait dengan pembuatan makna (meaning-making) melalui interaksi dan partisipasi aktif, yang memungkinkan organisasi mampu beradaptasi (berubah) dan mengatur pertumbuhannya secara self-organizing (Holtzhausen 2000). Dengan demikian, penciptaan situasi kerja yang saling memahami antar aktor komunikasi dalam rangka menjalin kerjasama harus dibangun melalui proses komunikasi yang berlangsung terus-menerus. Sehingga tercipta proses saling memahami antar aktor melalui discourse dan co-creation meaning, sebagai tahapan pembangunan atau penguatan budaya organisasi yang merupakan manifestasi learning organization dalam rangka adaptasi lingkungan untuk menciptakan keunggulan kompetitif. Pembentukan budaya organisasi seperti ini bersifat bottom-up atau dari bawah-ke-atas, mengingat interaksi saling memahami membutuhkan kesetaraan posisi aktor (van Ruler 2018) dan bukan nilai-nilai yang dipaksakan dari top management.

Di sisi lain, proses saling memahami sampai terbangunya budaya organisasi akan menciptakan learning organization yang khas antar aktor dalam bekerjasama mencapai tujuan organisasi (adaptasi/keunggulan kompetitif). Dengan demikian, kualitas kerjasama ditentukan oleh kualitas interaksi yang saling memahami antar aktor komunikasi. Berdasarkan pemikiran itu, logikanya kualitas komunikasi antar aktor menentukan ciri-ciri budaya organisasi yang terbentuk dan sifat kerjasama yang terbangun. Lebih dari itu, gagasan terpenting dari pemikiran ini adalah aktor komunikasi harus dipandang sebagai "active participant" atau bahkan "activist" dalam rangka internal change, yang mampu mereduksi perbedaan dan konflik, serta terus membangun keseimbangan kepentingan melalui interaksi yang positif di mana discourse, cocreation meaning, understanding (reflective dan sensitive), sharing knowledge, bisa dilakukan guna mencapai tujuan organisasi (Smith 2013).

\section{SIMPULAN}

Berbagai gagasan yang dijabarkan dalam artikel ini telah memberikan makna baru bagi pengembangan teorisasi strategic communication. Harapannya strategic communication mampu menjadi disiplin ilmu yang mandiri dan mampu keluar dari logika yang telah mapan. Memaknai strategic communication dengan berbasis paradigma postmodernitas adalah bentuk usaha nyata untuk menarik keluar kajian ini dari kungkungan logika modernitas yang selalu fokus pada tujuan komunikasi, di mana umumnya diimplementasikan dengan cara-cara komunikasi

yang bersifat linier (tradisional).

Dalam memaknai strategic communication, artikel ini juga telah merumuskan definisi baru yang mencoba menawarkan perspektif lain dengan menempatkan aktor-aktor komunikasi dan kualitas komunikasi-sebagai hasil interaksi antar aktormenjadi kajian utamanya. Penulis tidak mengharapkan bahwa apa yang telah dijabarkan dalam artikel ini merupakan kebenaran mutlak yang tidak bisa dikritisi. Dengan demikian, perlunya diuji berbagai ide yang telah diungkapkan, baik secara teoretis (pada tataran konsep dan teori) atau bahkan uji lapangan, guna mencari kebenaran ilmiah dengan tujuan membangun strategic communication menjadi disiplin baru yang bisa dipertanggungjawabkan secara keilmuan.

Demikian juga, berbagai ide yang telah diungkapkan dalam artikel ini bisa digunakan sebagai dasar penelitian selanjutnya. Beberapa konsep dan peneorian yang perlu diteliti lebih lanjut, seperti kaitan antara strategic communication dengan conflict management, learning organization, maupun teknologi komunikasi dan posisi aktor dalam organisasi, serta perlunya pengujian atas tujuan dari strategic communication adalah adaptasi lingkungan dan/atau keunggulan kompetitif yang berbasis pada sumber daya manusia, alih-alih hanya memikirkan profit semata, seperti kajian-kajian dalam disiplin lainnya yang berbasiskan pada paradigma modernitas.

\section{DAFTAR PUSTAKA}

Argenti, P.A., Howell, R.A., \& Beck, K.A. (2005). The Strategic Communication Imperative. MIT Sloan Management Review, 46(3), 82-89.

Argenti, P.A. (2017). Strategic Communication in the C-Suite. International Journal of Business Communication, 54(2), 146-160.

Bratianu, C. (2015). Organizational Knowledge Dynamics: Managing Knowledge Creation, Acquisition, Sharing, and Transformation. Hershey: IGI Global. DOI: 10.4018/978-1-46668318-1.ch012

Cheney, G., Christensen, L. T., Zorn, T., Jr., \& Ganesh, S. (2011). Organizational Communication in an Age of Globalization: Issues, Reflections, Practices (2nd ed.). Long Grove, IL: Waveland.

Cooren, F. (2006). Arguments for the in-depth study of organizational interactions: A rejoinder to McPhee, Myers, and Trethewey. Management Communication Quarterly, 19, 327-340. 
Bolderston, A. (2008). Writing an Effective Literature Review. Journal of Medical Imaging and Radiation Sciences, 39, 86-92.

Deborah Davis \& Barbara J. Daley (2008) The learning organization and its dimensions as key factors in firms' performance. Human Resource Development International, 11(1), 51-66.

Denney, A.S., \& Tewksbury, R.T. (2012). How to Write a Literature Review, Journal of Criminal Justice Education, DOI:10.1080/10511253.2012.730617.

Dervin, B. (1991). "Information as Nonsense; Information as Sense: The Communication Technology Connection." Dalam H. Bouwman, P. Nelissen, \& M. Vooijs (Eds.), Between Offer and Supply. Amsterdam, The Netherlands: Cramwinckel, 44-59.

Estaswara, H. (2015). Integrated Marketing Communications (IMC): Extended Version or New Idea? Journal of Global Academic Institute Education \& Social Sciences, 1(2), 123-139.

Estaswara, H. (2016). Integrated Marketing Communication (IMC) in Higher Education in Indonesia. Polish Journal of Management Studies, 14(1), 74-83.

Farwell, J.P. (2012). Persuasion and Power: The Art of Strategic Communication. Washington, DC, Georgetown University Press.

Freeman, R.E. (1984). Strategic Management: A Stakeholder Approach. Marshfield, MA: Pitman.

Falkheimer, J. \& Heide, M. (2014). From Public Relations to Strategic Communication in Sweden: The Emergence of a Transboundary Field of Knowledge. Nordicom Review, 35(2), 123-138.

Farwell, J. (2012). Persuation and Power: The Art of Strategic Communication. Washington DC: Georgetown University Press.

Grunig, J. (2006). Furnishing the Edifice: Ongoing Research on Public Relations as a Strategic Management Function. Journal of Public Relations Research, 18, 151-176.

Grunig, J. (2011). Public relations and strategic management: Institutionalizing organizationpublic relationships in contemporary society. Central European Journal of Communication, 1: 11-31.

Hallahan, K., Holtzhausen, D., van Ruler, B., Verčič, D., \& Sriramesh, K. (2007). Defining Strategic Com $\neg$ munication. International Journal of Strategic Communication, 1(1), 3-
35.

Holmström, S., Falkheimer, J., \& Nielsen, A.G. (2009). Legitimacyand Strategic Communication in Globalization: The Cartoon Crisis and Other Legitimacy Conflicts. International Journal of Strategic Communication, 4(1), 1-18.

Holtzhausen, D., \& Zerfass, A. (2014). "Strategic Communication: Opportunity and Chalanges in the Research Area." Holtzhausen, D.R., \& Zerfass, A. (Eds.). The Routledge Handbook of Strategic Communication. New York, NY:Routledge, 3-17.

Holtzhausen, D.R., \& Zerfass, A. (Eds.). (2014). The Routledge Handbook of Strategic Communication. New York, NY: Routledge.

Holtzhausen, D.R., (2000). Postmodern Values in Public Relations. Journal of Public Relations Research, 12(1), 93-114.

Jarzabkowski, P., Balogun, J., \& Seidl, D. (2007). Strategizing: The Challenges of a Practice Perspective. Human Relations, 60, 5-27.

Kaehler, B., \& Grundei, J. (2019). HR Governance A Theoretical Introduction. Springer.

Klerk, N.O., \& Sonja Verwey, S. (2013). Towards an emerging paradigm of strategic communication: Core driving forces, Communicatio. South African Journal for Communication Theory and Research, 39(3), 362-382.

Lyotard, J.F. (1992). Answering the question: What is postmodernism? In C. Jencks (Ed.), The postmodern reader. London: Academy Editions, 138-150.

Levy, Y., \& Ellis, T. J. (2006). A Systems Approach to Conduct an Effective Literature Review in Support of Information Systems Research. Informing Science Journal, 9, 181-212.

Madalina, O. (2016). Conflict Management, a new challenge. Procedia Economics and Finance, $39,807-814$.

Marchiori, M., \& Bulgacov, S. (2012). Strategy as Communicational Practice in Organizations. International Journal of Strategic Communication, 6, 199-211.

McAuley, J., Duberley, J., \& Johnson, P. (2007). Organization theory: Challenges and perspectives. UK: Pearson Education.

McPhee, R.D., \& Zaug, P. (2000). The

Communicative Constitution of Organizations: A Framework for Explanation. Electronic Journal of Communication, 10(1/2), 1-16. 
Mumby, D.K. (2011). Reframing difference in organizational communication studies: Research, pedagogy, practice. Thousand Oaks, California: Sage Publications.

Nothhaft, H., Werder, K.P., Verčič, D., \& Zerfass, A. (2018) Strategic Communication: Reflections on an Elusive Concept. International Journal of Strategic Communication, 12(4), 352-366.

Sandhu, S. (2009). Strategic Communication: An Institutional Perspective, International Journal of Strategic Communication, 3(2), 7292.

Schoeneborn, D., \& Vàsques, C. (2017). "Communicative Constitutive of Organisation." The International Encyclopedia of Organizational Communication. Dalam Scott, C.R., \& Lewis, L. (Editors-in-Chief), Barker, J.R., Keyton, J., Kuhn, T., \& Turner, P.K. (Associate Editors). John Wiley \& Sons, Inc.

Smith, B.G. (2013). The Internal Forces on Communication Integration: Co-Created Meaning, Interaction, and Postmodernism in Strategic Integrated Communication. International Journal of Strategic Communication, 7, 65-79.

Steyn, B. (2003). From strategy to corporate communication strategy: A conceptualization. Journal of Management Communication, 8, 168-182.

Thomas, F. \& Stephens, J. (2015). An Introduction to Strategic Communication. International Journal of Business Communication, 52(1), 311.

Turkalj, Z., Fosić, I., \& Dujak, D. (2008). Conflict Management in Organization. Interdisciplinary Management Research, 4: 505-515.

Torp, S.M. (2014). "The Strategic Turn in Communication Science: On the History and Role of Strategy in Communication Science from Ancient Greece until the Present Day." Holtzhausen, D.R., \& Zerfass, A. (Eds.). The Routledge Handbook of Strategic Communication. New York, NY:Routledge, 34-52.

van Ruler, B. (2018). Communication Theory: An Underrated Pillar on Which Strategic Communication Rests. International Journal of Strategic Communication, 12(4), 367-381.
Communication. International Journal of Strategic Communication, 12(4), 433-451.

Werder, K.P., Nothhaft, H., Verčič D., \& Zerfass, A. (2018). Strategic Communication as an Emerging Interdisciplinary Paradigm. International Journal of Strategic Communication, 12(4), 333-351. 